\title{
Textural behavior of gels formed by rice starch and whey protein isolate: Concentration and crosshead velocities
}

\section{Comportamento de textura de géis formados por amido de arroz e isolado proteico de soro: Concentrações e velocidades de teste}

\author{
Thiago Novaes Silva', Angélica Ribeiro da Costa', Edwin Elard Garcia-Rojas ${ }^{1 *}$
}

'Universidade Federal Fluminense/UFF, Volta Redonda, RJ, Brasil

${ }^{*}$ Corresponding author: edwin@vm.uff.br

Received in May 3, 2017 and approved in August 16, 2017

\begin{abstract}
Fabricated food gels involving the use of hydrocolloids are gaining polpularity as confectionery/convenience foods. Starch is commonly combined with a hydrocolloid (protein our polyssacharides), particularly in the food industry, since native starches generally do not have ideal properties for the preparation of food products. Therefore the texture studies of starch-protein mixtures could provide a new approach in producing starch-based food products, being thus acritical attribute that needs to be carefully adjusted to the consumer liking. This work investigated the texture and rheological properties of mixed gels of different concentrations of rice starch (15\%, 17.5\%, and $20 \%)$ and whey protein isolate $(0 \%, 3 \%$, and $6 \%$ ) with different crosshead velocities $(0.05,5.0$, and $10.0 \mathrm{~mm} / \mathrm{s})$ using a Box-Behnken experimental design. The samples were submitted to uniaxial compression tests with $80 \%$ deformation in order to determinate the following rheological parameters: Young's modulus, fracture stress, fracture deformation, recoverable energy, and apparent biaxial elongational viscosity. Gels with a higher rice starch concentration that were submitted to higher test velocities were more rigid and resistant, while the whey protein isolate concentration had little influence on these properties. The gels showed a higher recoverable energy when the crosshead velocity was higher, and the apparent biaxial elongational viscosity was also influenced by this factor. Therefore, mixed gels exhibit different properties depending on the rice starch concentration and crosshead velocity.
\end{abstract}

Index terms: Young's modulus; fracture; stress; rheology.

\begin{abstract}
RESUMO
Géis fabricados que envolvem o uso de hidrocolóides estão ganhando polpularidade como alimentos de confeitaria/conveniência. O amido é geralmente combinado com um hidrocolóide (proteínas ou polissacarideos), particularmente na indústria de alimentos, uma vez que os amidos nativos geralmente não têm propriedades ideais para a preparação de produtos alimentares. Por conseguinte, os estudos de textura de misturas de amido-proteína podem proporcionar uma nova abordagem na produção de produtos alimentares à base de amido, sendo assim um atributo acrítico que precisa ser cuidadosamente ajustado ao gosto do consumidor. Este trabalho investigou as propriedades reológicas de textura de géis mistos de diferentes concentrações de amido de arroz (15\%, 17,5\% e 20\%) e isolado proteico de soro $(0 \%, 3 \%$ e $6 \%)$ com diferentes velocidades de teste $(0,05,5,0$ e $10,0 \mathrm{~mm} / \mathrm{s})$ utilizando um delineamento experimental por Box-Behnken. As amostras foram submetidas a testes de compressão uniaxial com deformação de $80 \%$ para determinar os seguintes parâmetros reológicos: módulo de Young, tensão de fratura, deformação da fratura, energia recuperável e aparente viscosidade elongacional biaxial. Géis com maior concentração de amido de arroz e que foram submetidos a velocidades de teste mais altas mostraram-se mais rígidos e resistentes, enquanto que a concentração de isoldado proteico de soro teve pouca influência nessas propriedades. Os géis mostraram uma energia recuperável mais alta quando a velocidade de teste foi maior, e a viscosidade elongacional biaxial aparente também foi influenciada por este fator, exibindo propriedades diferentes dependendo da concentração de amido de arroz e da velocidade de teste.
\end{abstract}

Termos para indexação: Módulo de Young; fratura; tensão; reologia.

\section{INTRODUCTION}

Rice starch (RS) is the basic food of almost half of the population worldwide; therefore, it has great global, social, and political economic importance (Tan; Sun; Corke, 2002). Approximately $90 \%$ of the total dry weight of the polished rice grain is composed of starch, which is the main plant polysaccharide that occurs naturally in the form of granules in vegetable cells (Singh et al., 2003). RS is hypoallergenic, white in color, and has a smooth texture when it is in the form of a gel (Viturawong; Achayuthakan; Suphantharika, 2008). However, gels with starch alone have a tendency to synerese and retrograde when subjected to cooking, shear stress, and cooling, which can lead to gels with an increased hardness and the formation of 
undesirable gels (Rosell; Yokoyama; Shoemaker, 2011). Starch is commonly combined with a hydrocolloid, particularly in the food industry, since native starches generally do not have ideal properties for the preparation of food products. Therefore, these combinations are used to modify the rheological and texture properties in order to improve humidity retention, control water mobility, and maintain general product quality during food processing and storage (Samutsri; Suphantharika, 2012).

Whey and starch mixtures have received attention from researchers because whey proteins can form gels under certain temperatures and salt and protein concentrations, offering new possibilities when they are heated in the presence of starch dispersions. Thus, a continuous phase of mixed gels can be made by these protein and starch polymers, forming a network (Considine et al., 2011). Important functional properties of whey protein products include their ability to form heat-induced gels as well as to provide texture and water retention properties for food (Frydenberg et al., 2016).

Food gels containing RS are increasingly becoming an option for the manufacture of gluten-free products, also known as gluten free, mainly for the growing market of people looking for a healthier diet and also for those who have some food restrictions such as those with celiac disease or diabetes. Substitution of ingredients or reformulation of existing food products may result in poor product quality due to changes in the textural characteristics, which depend on the concentrations of the components (Çakir et al., 2012). In addition, the fracture behavior is an important quality feature for product development (Sharma; Bhattacharya, 2014). Texture is one of the most important sensory attributes that determines the quality and acceptance of food by consumers (Çakir et al., 2012). During processing and use, food products are subjected to stress, including normal stress; therefore, compression tests are used to determine important properties of these foods. Compression is an efficient method to evaluate food texture, mainly because of its similarity to the chewing action (Sharma; Bhattacharya, 2014). Properties such as Young's modulus, true stress, and true strain can be found using this type of test (de Jong; Van de Velde, 2007). Some studies using uniaxial compression with large deformations of gels have been reported, including those of mixed gels of carrageenan protein (Çakir et al., 2012), gels with hydrocolloids (gellan gum and agar) (Sharma; Bhattacharya, 2014), gels with proteins (de Jong; Van Vliet; de Jongh, 2015), gelatinous gels with soy protein isolate (Ersch et al., 2015), and gels with pea protein (Munialo; Van Der Linden; de Jongh,
2014). In order to understand the macroscopic properties of mixed gels, it is important to identify the gelation process that is responsible for gel formation (de Jong; Van de Velde, 2007). Heat gelation is a method commonly used to obtain a gel (de Jong; Van Vliet; de Jongh, 2015).

Due to the increased consumption of gluten-free products, which include RS, and the limited amount of research in this area, the aims of this study were to evaluate the texture properties of mixed gels containing RS and whey protein isolate (WPI) and to elucidate how they are influenced by crosshead velocity. Important parameters such as Young's modulus, fracture stress, strain, recoverable energy, biaxial extensional rate, and apparent biaxial elongational viscosity were determined.

\section{MATERIAL AND METHODS}

\section{Material}

RS was purchased from Sigma Aldrich (St. Louis, MO, USA) and WPI was from Glanbia Nutritionals (Fitchburg, WI, USA). Ultrapure water with a conductivity of $0.05 \mu \mathrm{S} / \mathrm{cm}$ (Master System P \& D, Gehaka, São Paulo, Brazil) was used in all tests.

\section{Methods}

\section{Preparation of the gels}

The gels were prepared by thermal gelation (Kong; Kasapis; Bao, 2015). Adequate amounts of RS, WPI, and water were weighed (Shimadzu, AY220, Japan) and mixed with a magnetic stirrer for $10 \mathrm{~min}$. Next, the sample was placed in a thermostatic bath at $90{ }^{\circ} \mathrm{C}$ for $30 \mathrm{~min}$, under constant manual stirring for $9 \mathrm{~min}$ to avoid the formation of lumps (Marfil; Anhê; Telis, 2012). The RS concentrations were $15.0 \%, 17.5 \%$, and $20 \%(\mathrm{w} / \mathrm{w})$, whereas those of the WPI were $0.0 \%, 3.0 \%$, and $6.0 \%(\mathrm{w} / \mathrm{w})$. The samples were covered with plastic film in order to prevent dehydration and were kept refrigerated at $4{ }^{\circ} \mathrm{C}$ for $24 \mathrm{~h}$.

\section{Compression test}

ATAXTplus texture analyzer (Stable Micro Systems, Godalming, UK) was used to carry out the tests. The samples had a cubic shape, with an edge of $1.5 \mathrm{~cm}$, and were lubricated with vegetable oil in order to avoid loss of moisture and to reduce friction. The gels were uniaxially compressed to $80 \%$ of the initial height using a $75-\mathrm{mm}$-diameter $(\mathrm{P} / 75)$ cylindrical plate. The pretest velocity was $1 \mathrm{~mm} / \mathrm{s}$; the compression velocities ranged according to the experimental design $(0.05,5.0$, and $10.0 \mathrm{~mm} / \mathrm{s})$ and the post-test velocity was 10 
$\mathrm{mm} / \mathrm{s}$ for determination of the texture parameters (Sharma; Bhattacharya, 2014). The tests were performed twice.

The compression characteristics can be expressed in terms of true strain $(\varepsilon)$ and true stress $(\sigma)$ according to Equations 1 and 2, respectively (Sharma and Bhattacharya, 2014):

$\varepsilon=\ln \left(\frac{h_{0}}{h_{0}-\Delta h}\right)$

$\sigma=\frac{F\left(h_{0}-\Delta h\right)}{A h_{0}}$

where $h_{0}$ is the initial height of the sample, $\mathrm{F}$ is the force during compression, $\Delta h$ is the variation of the height of the sample during the compression test, and $A$ is the crosssectional area of the sample.

The Young's modulus $(E)$ was calculated from the linear slope of the stress-strain curve up to $5 \%$ deformation (Çakir et al., 2012) and described by Equation 3 (Bourne, 1982):

$E=\frac{F \cdot L_{0}}{A \cdot \Delta L}$

where $F$ is the force value applied at $5 \%$ deformation, $L_{0}$ is the initial height, $A$ is the cross-sectional area of the sample at tension, and $\Delta L$ is the variation of the sample height during the compression test.

The recoverable energy (RE) of the material was calculated according to Equation 4 (de Jong; Van Vliet; de Jongh, 2015):

$R E=\frac{W_{d}}{W_{c}} \times 100 \%$

where $W_{c}$ is the work required to compress the sample as determined by the positive area of the stress-strain curve, and $W_{d}$ is the work released by the sample as determined by the negative area of the stress-strain curve.

For calculation of the biaxial extensional rate $\left(\dot{\varepsilon}_{r}\right)$ and the apparent biaxial elongational viscosity $\left(\eta_{b}\right)$, Equations 5 and 6, respectively, were applied (Ramires-Wong et al., 1996):

$\varepsilon_{r}=\frac{v(t)}{2 \cdot h(t)}$
$\eta_{b}=\frac{F(t) \cdot h(t)}{A \cdot h_{0} \cdot \varepsilon_{r}}$

where $v(t)$ is the compression velocity used in the test, $h(t)$ is the height of the sample at time t, $F(t)$ is the force applied to the sample at time t, $A$ is the cross-sectional area of the sample at tension, and $h_{0}$ is the initial height of the sample.

\section{Experimental design and statistical analysis}

The Box-Behnken (Ba-Abbad et al., 2015) experimental design with three variables and three levels was used to study the combined effect of RS (15-20\%), WPI (0$6 \%$ ), and crosshead velocity $(0.05-10 \mathrm{~mm} / \mathrm{s})$ on the following texture parameters: strain, fracture stress, Young's modulus, and recoverable energy. The variables and their levels are presented in Table 1. The design consisted of 4 combinations of factor levels plus 1 central point and 2 replicates, totaling 26 experimental units. A second-degree polynomial equation (Equation 7) was used to fit the experimental data (Bayraktar, 2001; Jha et al., 2013; Sadeghi et al., 2014):

$Y=\beta_{0}+\beta_{1} x_{1}+\beta_{2} x_{2}+\beta_{3} x_{3}+\beta_{12} x_{1} x_{2}+\beta_{13} x_{1} x_{3}+\beta_{23} x_{2} x_{3}+\beta_{11} x_{1}^{2}+\beta_{22} x_{2}^{2}+\beta_{33} x_{3}^{2}$

where $Y$ is the predicted response associated with each independent variable; $x_{1}, x_{2}$, and $x_{3}$ represent the independent variables; $\beta_{0}$ is the constant; $\beta_{1}, \beta_{2}$, and $\beta_{3}$ are the linear coefficients; $\beta_{12}, \beta_{13}$, and $\beta_{23}$ are the interaction coefficients between the three factors; and $\beta_{11}, \beta_{22}$, and $\beta_{33}$ are the quadratic coefficients. Data analysis was performed using Statistical Analysis System, version 9.0 (SAS ${ }^{\circledR}$ Institute Inc., Cary, NC, USA). Analysis of variance and regression analysis with significance of $10 \%$ were performed.

\section{RESULTS AND DISCUSSION}

From the data obtained, force-deformation curves were made. The response variables, including strain (Equation 1), fracture stress (Equation 2), Young's modulus (Equation 3), and recoverable energy (Equation 4), are shown in Table 1.

\section{Young's modulus}

The Young's modulus (E), which is a measure of the stiffness of a material (Munialo; Van Der Linden; de Jongh, 2014; Munialo et al., 2015), was calculated from the slope of the linear region of the stess-strain curve up to $5 \%$ of deformation (Çakir et al., 2012). Equation 8 after statistical analysis of the data shows the empirical relationship between the Young's modulus and the variables studied. 
Table 1: Experiment planning and data for modeling texture characterization.

\begin{tabular}{|c|c|c|c|c|c|c|c|c|c|c|}
\hline \multirow{2}{*}{ RUN } & \multicolumn{3}{|c|}{ Coded values } & \multicolumn{3}{|c|}{ Real values } & \multirow{2}{*}{$\begin{array}{l}\text { Young } \\
(\mathrm{kPa})^{\star}\end{array}$} & \multirow{2}{*}{$\begin{array}{l}\text { Stress } \\
(\mathrm{kN})^{*}\end{array}$} & \multirow{2}{*}{ Strain* } & \multirow{2}{*}{$\begin{array}{c}\text { Rec. } \\
\text { Energy }\end{array}$} \\
\hline & $\mathrm{RS}$ & WPI & VEL & RS & WPI & VEL & & & & \\
\hline 1 & -1 & -1 & 0 & 15 & 0 & 5.00 & 10.09 & 1.59 & 1.82 & 10.94 \\
\hline 2 & -1 & 1 & 0 & 15 & 6 & 5.00 & 8.72 & 2.95 & 1.54 & 7.68 \\
\hline 3 & 1 & -1 & 0 & 20 & 0 & 5.00 & 12.37 & 3.25 & 1.94 & 8.02 \\
\hline 4 & 1 & 1 & 0 & 20 & 6 & 5.00 & 11.99 & 3.87 & 1.84 & 4.15 \\
\hline 5 & 0 & -1 & -1 & 17.5 & 0 & 0.05 & 8.58 & 2.35 & 1.64 & 0.74 \\
\hline 6 & 0 & -1 & 1 & 17.5 & 0 & 10.00 & 9.63 & 2.44 & 1.78 & 13.17 \\
\hline 7 & 0 & 1 & -1 & 17.5 & 6 & 0.05 & 9.15 & 2.20 & 1.97 & 0.51 \\
\hline 8 & 0 & 1 & 1 & 17.5 & 6 & 10.00 & 12.05 & 5.13 & 1.66 & 7.67 \\
\hline 9 & -1 & 0 & -1 & 15 & 3 & 0.05 & 7.19 & 1.81 & 1.80 & 0.61 \\
\hline 10 & 1 & 0 & -1 & 20 & 3 & 0.05 & 10.50 & 2.37 & 1.97 & 0.55 \\
\hline 11 & -1 & 0 & 1 & 15 & 3 & 10.00 & 8.64 & 2.60 & 1.56 & 8.75 \\
\hline 12 & 1 & 0 & 1 & 20 & 3 & 10.00 & 13.09 & 4.46 & 1.81 & 6.73 \\
\hline 13 & 0 & 0 & 0 & 17.5 & 3 & 5.00 & 11.17 & 3.88 & 1.66 & 8.32 \\
\hline
\end{tabular}

* average.

$E=-2419.47+666.01 R S+200.65 V E L$

(8)

where RS, WPI, and VEL indicate the RS concentration, WPI concentration, and test velocity, respectively.

The lack of adjustment $(\mathrm{P}=0.725)$ and the ratio of lack of fit to pure error (0.444), presented in Table 2, showed that the proposed model is adequate to describe the data. $\mathrm{R}^{2}$ value $(91.14 \%)$ of model showed a very good correlation between the experimental and predicted values. The significance of each term was obtained according to the Pareto principle, which states that among the many factors influencing the response, only a few are responsible for most of the impact (Sadeghi et al., 2014). The $\mathrm{P}$ values are described in Table 2 and determine the significance of each factor, i.e., the smaller the magnitude of the $\mathrm{P}$ value, the more significant the corresponding term (Bayraktar, 2001). Following this principle, the RS concentration was the most significant term for Young's modulus determination, followed by the test velocity. The linear model was the best one that fit the studied response.

As shown in the contour plot in Figure 1, the Young's modulus ranged from $7.5 \mathrm{kPa}$ for RS-WPI gel 15-3 with a velocity of $0.05 \mathrm{~mm} / \mathrm{s}$ to $12.9 \mathrm{kPa}$ for RS-WPI gel $20-3$ with a velocity of $10 \mathrm{~mm} / \mathrm{s}$. The stiffness of the gel increased as the velocity and RS concentration increased, making it more resistant. While at a low velocity and a low RS concentration, a weaker gel was produced. This finding can be explained by the fact that as the RS concentration increases, the amount of water in the medium decreases; therefore, the granules cannot swell enough and become more rigid (Ersch et al., 2015). Similar behaviors regarding the rigidities of gellan and xanthan gum gels (de Jong; Van de Velde, 2007), gelatin and soy protein isolate gels (Ersch et al., 2015), pea protein gels (Munialo et al., 2015), and whey protein gels (Munialo et al., 2016) have been reported in previous studies. Young's modulus should not vary for an ideal solid with different compression velocities under experimental conditions, but gels are viscoelastic products and may behave differently (Sharma; Bhattacharya, 2014). An increasing stiffness of gels with an increasing polysaccharide concentration may be related to an increased local polysaccharide concentration and an improved interaction between aggregated proteins, thus leading to increased gel stiffness, whereby higher forces are required for deformation (Munialo et al., 2016).

\section{Strain}

The fracture strain indicates the brittleness of a gel (Munialo; Van Der Linden; de Jongh, 2014; Munialo et al., 2016). It was observed that no variables contributed significantly to gel deformation, since $\mathrm{P}>0.05$ for all parameters, indicating that the gels were equally brittle (Table 3). Previous studies also have reported that strain does not depend on the polysaccharide/protein concentration (Wang et al., 2014; Munialo et al., 2015; Munialo et al., 2016). 
Table 2: Terms of the quadratic model with their significance and analysis of variance (ANOVA) for the Young's module.

\begin{tabular}{|c|c|c|c|c|c|}
\hline \multirow{2}{*}{ Source } & \multicolumn{5}{|c|}{ Master Model } \\
\hline & DF & SS & MS & $\mathrm{F}$ & $\mathrm{Pr}>\mathrm{F}$ \\
\hline RS & 1 & $4.4 \mathrm{E}+07$ & $4.4 \mathrm{E}+07$ & 9.692 & 0.007 \\
\hline VEL & 1 & $1.6 \mathrm{E}+07$ & $1.6 \mathrm{E}+07$ & 3.484 & 0.080 \\
\hline Model & 9 & $7 E+07$ & 7793494 & 1.703 & 0.169 \\
\hline (Linear) & 3 & $6.1 \mathrm{E}+07$ & $2 \mathrm{E}+07$ & 4.420 & 0.019 \\
\hline (Quadratic) & 3 & 6601196 & 2200399 & 0.481 & 0.700 \\
\hline Error & 16 & $7.3 \mathrm{E}+07$ & 4576514 & & \\
\hline (Lack of fit) & 3 & 6811990 & 2270663 & 0.444 & 0.725 \\
\hline (Pure Error) & 13 & $6.6 \mathrm{E}+07$ & 5108633 & & \\
\hline Total & 25 & $1.4 \mathrm{E}+12$ & & & \\
\hline
\end{tabular}

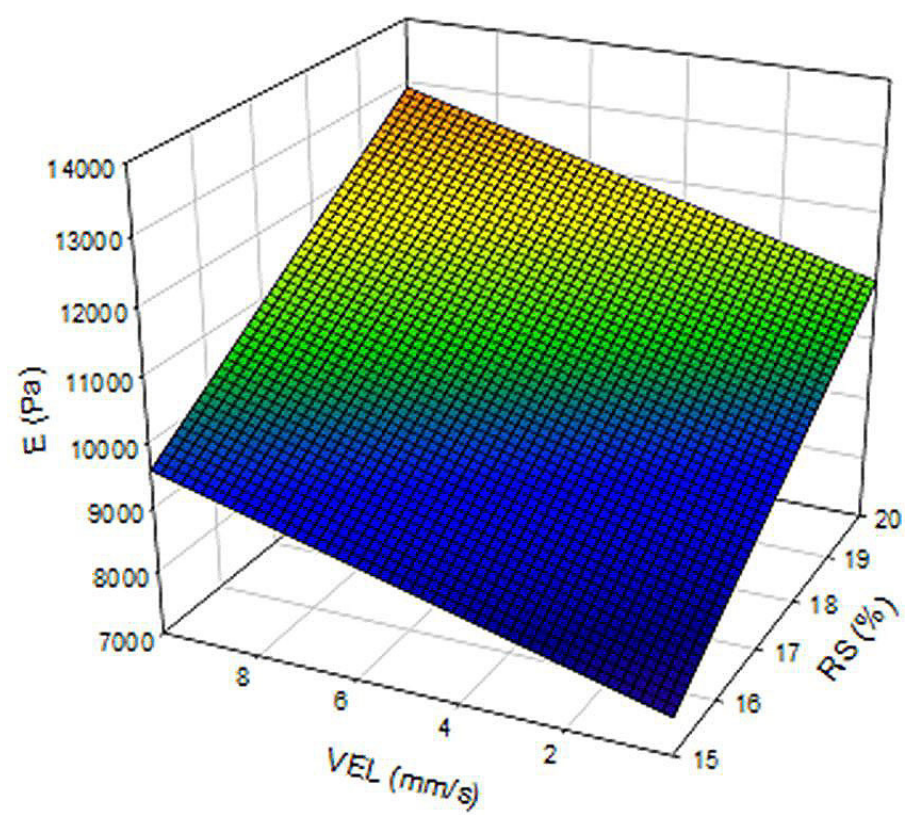

Figure 1: Contour plot showing the influence of RS and velocity on Young's modulus.

\section{Fracture stress}

The fracture stress (FS) indicates the brittleness of a gel (Munialo; Van Der Linden; de Jongh, 2014), and the relationship between fracture stress and the studied variables can be described by Equation 9 after statistical analysis of the data:

$F S=-1974.88+249.95 R S-50.87 W P I+5.41 V E L+47.66 W P I \times V E L$
The lack of adjustment was not significant $(\mathrm{P}=$ 0.99), and the pure error (0.03) presented in Table 4 showed that the proposed model (Equation 7) adequately described the data. $\mathrm{R}^{2}$ value $(99.66 \%$ ) of model showed a very good correlation between the experimental and predicted values. The first-order effect of velocity was the most significant term to determine fracture stress, followed by the RS and WPI concentrations, and then the cross-product between the WPI concentration and test velocity, respectively. 
Table 3: Terms of the quadratic model with their significance and analysis of variance (ANOVA) for the strain.

\begin{tabular}{cccccc}
\hline \multirow{2}{*}{ Source } & \multicolumn{5}{c}{ Master Model } \\
\cline { 2 - 6 } & $\mathrm{DF}$ & $\mathrm{SS}$ & $\mathrm{MS}$ & $\mathrm{F}$ & $\mathrm{Pr}>\mathrm{F}$ \\
\hline $\mathrm{RS}$ & 1 & 0.179358 & 0.179358 & 2795269 & 0.113982 \\
WPI & 1 & 0.008569 & 0.008569 & 0.133542 & 0.719574 \\
VEL & 1 & 0.081039 & 0.081039 & 1262984 & 0.277666 \\
RS*RS & 1 & 0.023794 & 0.023794 & 0.370822 & 0.551105 \\
RS*WPI & 1 & 0.018426 & 0.018426 & 0.287165 & 0.599414 \\
RS*VEL & 1 & 0.003946 & 0.003946 & 0.061496 & 0.807302 \\
WPI*WPI & 1 & 0.01196 & 0.01196 & 0.186388 & 0.671702 \\
WPI*VL & 1 & 0.103744 & 0.103744 & 1616829 & 0.221708 \\
VEL*VEL & 1 & 0.012413 & 0.012413 & 0.193451 & 0.665943 \\
& & & & & \\
Model & 9 & 0.422574 & 0.046953 & 0.73175 & 0.675543 \\
(Linear) & 3 & 0.268966 & 0.089655 & 1397265 & 0.279938 \\
(Quadratic) & 3 & 0.027492 & 0.009164 & 0.142821 & 0.932778 \\
(Cross Product) & 3 & 0.126115 & 0.042038 & 0.655163 & 0.591351 \\
Error & 16 & 1026638 & 0.064165 & & 0.723432 \\
(Lack of fit) & 3 & 0.096042 & 0.032014 & 0.44722 & \\
(Pure Error) & 13 & 0.930596 & 0.071584 & & \\
Total & 25 & 1449212 & & &
\end{tabular}

Table 4: Quadratic model terms with their significance and analysis of variance (ANOVA) for fracture stress.

\begin{tabular}{crrrrr}
\hline \multirow{2}{*}{ Source } & \multicolumn{5}{c}{ Master Model } \\
\cline { 2 - 6 } & DF & SS & MS & F & \multicolumn{1}{c}{$\operatorname{Pr}>\mathrm{F}$} \\
\hline RS & 1 & 6247693 & 6247693 & 7261531 & 0.015943 \\
WPI & 1 & 5124697 & 5124697 & 5956302 & 0.026672 \\
VEL & 1 & 8721872 & 8721872 & 101372 & 0.00577 \\
WPI*VEL & 1 & 4048662 & 4048662 & 4705655 & 0.045473 \\
& & & & & \\
Model & 9 & 27148607 & 3016512 & 3506013 & 0.013958 \\
(Linear) & 3 & 20094262 & 6698087 & 7785012 & 0.00199 \\
(Quadratic) & 3 & 1889857 & 629952.5 & 0.732177 & 0.54782 \\
Error & 16 & 13766118 & 860382.4 & & \\
(Lack of fit) & 3 & 93065.39 & 31021.8 & 0.029495 & 0.992841 \\
(Pure Error) & 13 & 13673052 & 1051773 & & \\
Total & 25 & 40914725 & & & \\
\hline
\end{tabular}


The contour curves represent a combination of two variables, with a third variable maintained at mid-level (Bayraktar, 2001; Sadeghi et al., 2014). Figure 2a shows fracture stress as a function of RS and WPI concentrations. The gel had a higher fracture stress when it had higher RS and WPI concentrations, but the WPI concentration had less of an influence on the resistance of the material. Figure $2 b$ shows the fracture stress as a function of the RS concentration and crosshead velocity. It can be observed that the fracture stress of the gel increases with an increasing RS concentration and crosshead velocity, making it more resistant to a higher RS concentration and compression velocity. Figure $2 \mathrm{c}$ shows the fracture stress as a function of the WPI concentration and crosshead velocity. For a low test velocity and a low WPI concentration, there was not much variation in the resistance of the material. This parameter was influenced when the material was subjected to a high test velocity and a high WPI concentration.

Wang et al. (2014) have studied the texture properties of agar gels and concluded that the fracture stress increases with an increasing agar concentration at all compression velocities studied and that the dependence of the fracture concentration is stronger at a faster compression velocity. Munialo et al. (2016) also have reported that the fracture stress increases as the pectin concentration increases.

\section{Recoverable energy}

Recoverable energy represents the energy that is stored elastically during deformation. Equation 10, after statistical analysis of the data, shows the empirical relationship between the recoverable energy (RE) and the variables studied:

$R E=9.57-0.43 R S-0.54 W P I+2.06 V E L-0.12 V E L^{2}$

$\mathrm{P}$ value for lack of fit $(0.309617)$ and the ratio of lack of fit to pure error (1.321913) showed that the proposed model adequately described the data (Table 5). $\mathrm{R}^{2}$ value $(97.21 \%)$ of model showed a very good correlation between the experimental and predicted values. The firstorder effect of velocity was the most significant term in the determination of the recoverable energy of the gel, followed by the second order of the velocity and the first order of the WPI and RS concentrations, respectively. The gels that were submitted to higher test velocities were the ones with the highest recoverable energy, around $10 \%$; while at lower velocities, their recovery was practically null. (a)

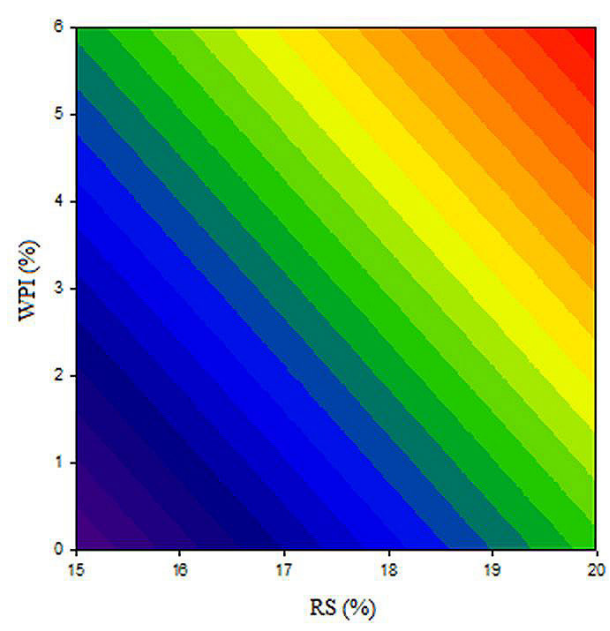

(b)

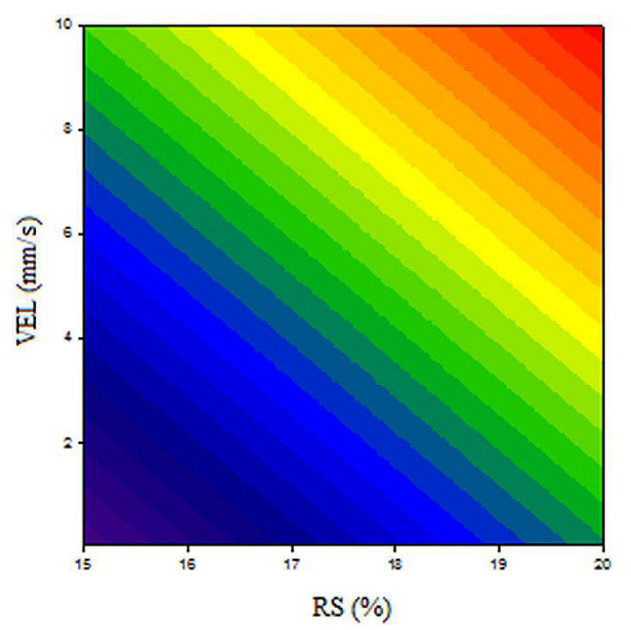

(c)

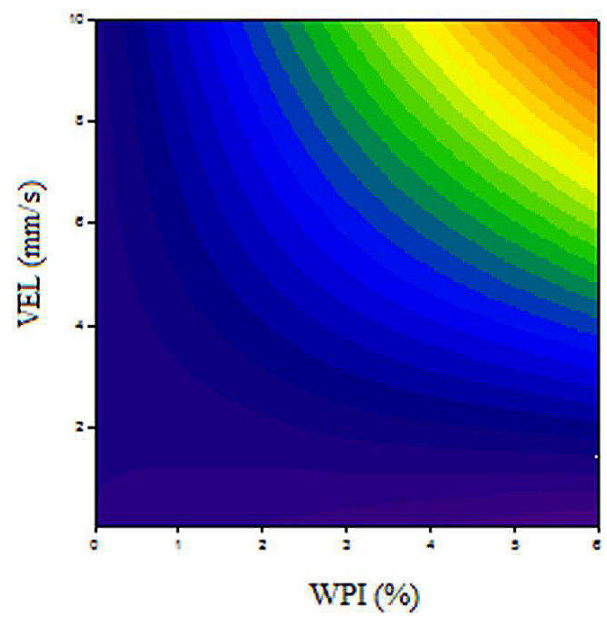

Figure 2: Contour curves showing the influence of different variables on the fracture stress of the gels: (a) RS and WPI, (b) RS and velocity and (c) WPI and velocity. 
Table 5: Terms of the quadratic model with their significance and analysis of variance (ANOVA) for recoverable energy.

\begin{tabular}{|c|c|c|c|c|c|}
\hline \multirow{2}{*}{ Source } & \multicolumn{5}{|c|}{ Master Model } \\
\hline & $\mathrm{DF}$ & SS & MS & $\mathrm{F}$ & $\mathrm{Pr}>\mathrm{F}$ \\
\hline RS & 1 & 1817817 & 1817817 & 5573265 & 0.031262 \\
\hline WPI & 1 & 413758 & 413758 & 1268545 & 0.002602 \\
\hline VEL & 1 & 2875934 & 2875934 & 8817357 & 0.0001 \\
\hline VEL*VEL & 1 & 4583273 & 4583273 & 1405191 & 0.001753 \\
\hline Model & 9 & 4257915 & 4731017 & 1450488 & 0.0001 \\
\hline (Linear) & 3 & 3471474 & 1157158 & 3547743 & 0.0001 \\
\hline (Quadratic) & 3 & 626749 & 2089163 & 6405188 & 0.004677 \\
\hline Error & 16 & 5218678 & 3261674 & & \\
\hline (Lack of fit) & 3 & 1219865 & 4066217 & 1321913 & 0.309617 \\
\hline (Pure Error) & 13 & 3998813 & 307601 & & \\
\hline Total & 25 & 4779783 & & & \\
\hline
\end{tabular}

Figure 3a shows the recoverable energy as a function of the RS and WPI concentrations. The energy increased with a decrease in the RS and WPI concentrations. Figures $3 b$ and $3 c$ represent the recoverable energy as a function of the test velocity with the RS and WPI concentrations, respectively. Both curves had the same behavior: as the test velocity increased, the recoverable energy of the gel increased; the maximum recoverable energy values for RS and WPI were $10.1 \%$ and $10.7 \%$, respectively. For all situations, it was observed that the gels without protein were the ones that had a higher recoverable energy because the gels with a greater amount of water retained within in the network tended to be more elastic, thus affording a higher recoverable energy (Munialo; Van Der Linden; de Jongh, 2014). When a material is subjected to a high compression velocity, there is insufficient time for the total breakdown of its structure; therefore, there is more recovery and a higher recoverable energy is presented (Sharma; Bhattacharya, 2014).

Recoverable energy also can be analyzed by force-strain curves. The force-strain curves for one of the RS-WPI gels at test velocities of $0.01,1$, and $10 \mathrm{~mm} / \mathrm{s}$ are shown in Figures $4 \mathrm{a}, 4 \mathrm{~b}$, and $4 \mathrm{c}$, respectively. It was observed that as the test velocity during the compression increased, the recovery of the sample increased, as indicated by the smaller negative area in the graph during the decompression (Figure 4c). The inverse behavior was observed at a lower velocity, where there was a greater energy loss and less sample restructuring (Figure 4a). The gel fractures at the point where the curve stops growing and begins to decay. In some cases, it is not possible to identify the breakpoint of a gel. Similar curves have been reported in the literature to be related to the behavior of agar gel (Sharma; Bhattacharya, 2014).

\section{Apparent biaxial elongational viscosity}

The apparent biaxial elongational viscosity $\left(\eta_{\mathrm{b}}\right)$ versus the biaxial extensional rate $\left(\dot{\varepsilon}_{\mathrm{r}}\right)$ for mixed gels of $\mathrm{RS}$ and WPI at different test velocities $(0.05,0.5,0.1$, 1,5 , and $10 \mathrm{~mm} / \mathrm{s}$ ) is shown in Figure 5. The graphs for all RS-WPI concentrations are similar, varying only in magnitude. The increase of $\dot{\varepsilon r}$ causes a decrease of the $\eta_{b}$ value, meaning that a decrease in gel strength occurs when the compression test velocity increases (Sharma; Bhattacharya, 2014). Two regions can be observed in the graphs: one with a sharp increase of the curve until a peak viscosity is reached, and another region with a slight decay until a constant viscosity is maintained, which looks like a Newtonian region, where the viscosity is constant, independent of the biaxial extensional rate (Ramires-Wong et al., 1996). At high test velocities, there was an increase in the viscosity until a peak value was reached, followed by a prolonged nonlinear decay. The pattern of the gel curves is much more complex when compared to other types of mass (Sharma; Bhattacharya, 2014). 
(a)

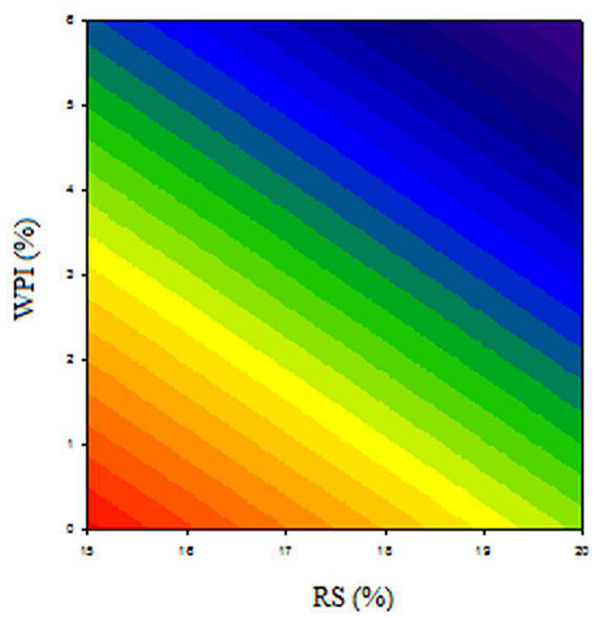

(b)

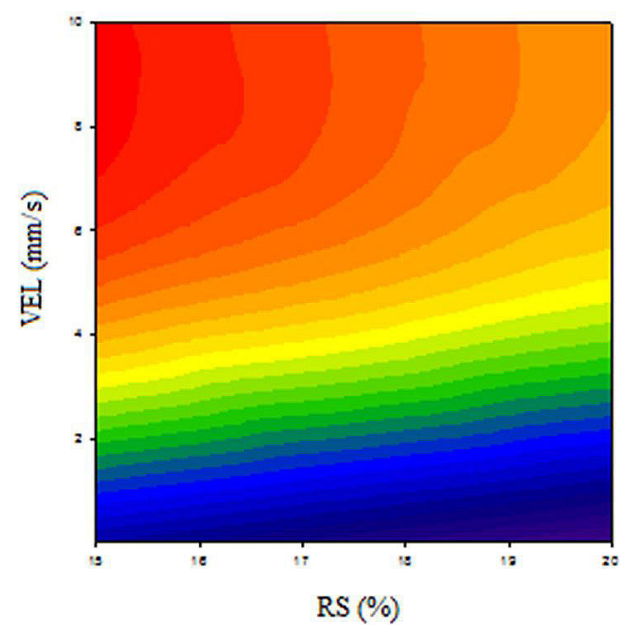

(c)

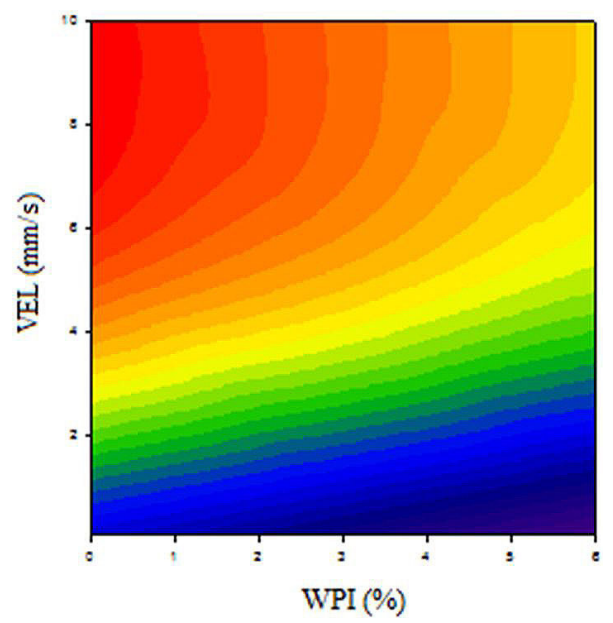

Figure 3: Contour curves showing the influence of different variables on the recoverable energy of the gels: (a) RS and WPI, (b) RS and velocity and (c) WPI and velocity. (a)

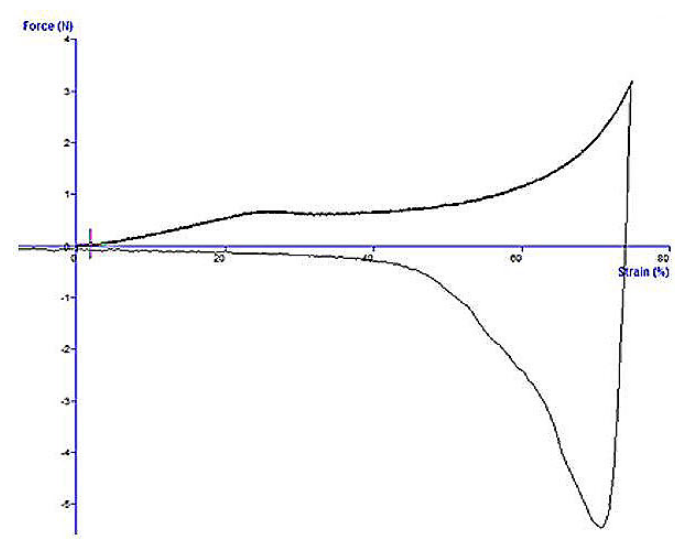

(b)

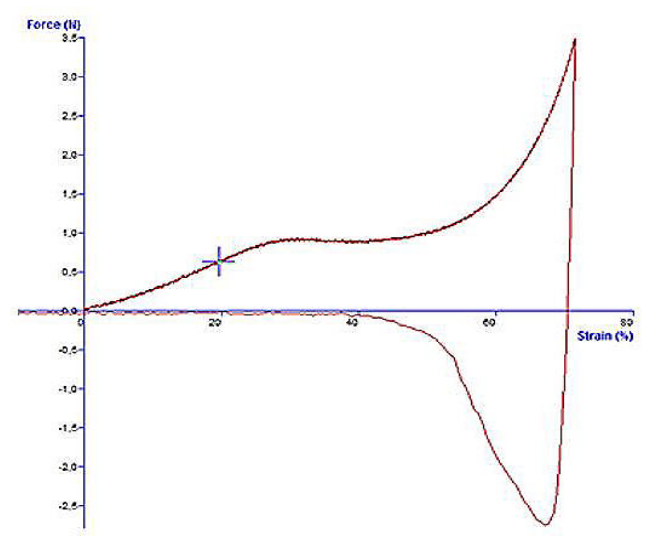

(c)

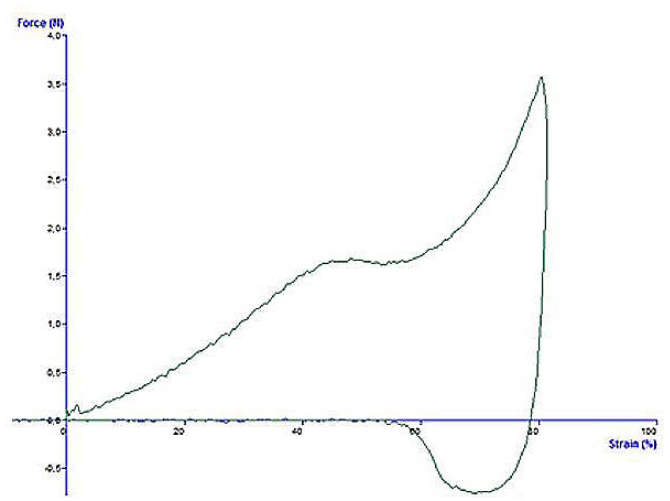

Figure 4: Force-deformation curves for velocities of (a) $0.01 \mathrm{~mm} / \mathrm{s}$, (b) $1 \mathrm{~mm} / \mathrm{s}$ and (c) $10 \mathrm{~mm} / \mathrm{s}$. 
(a)

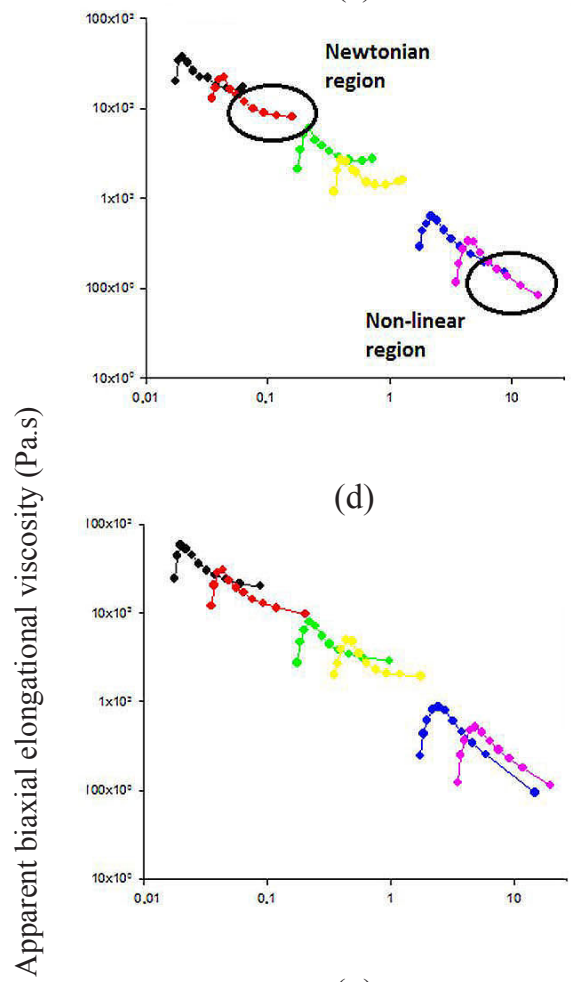

(g)

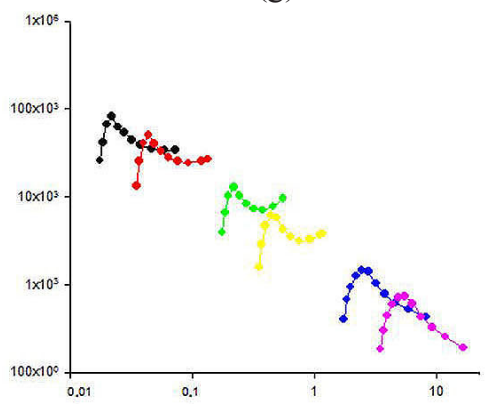

(b)

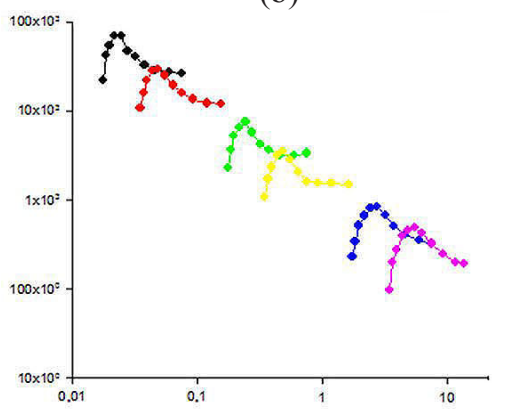

(e)

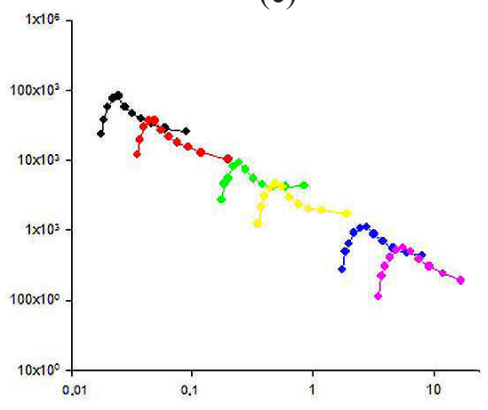

(h)

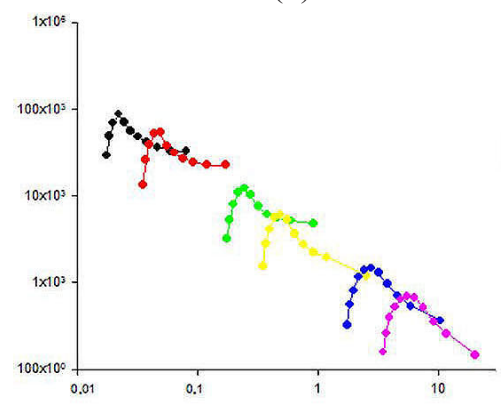

(c)

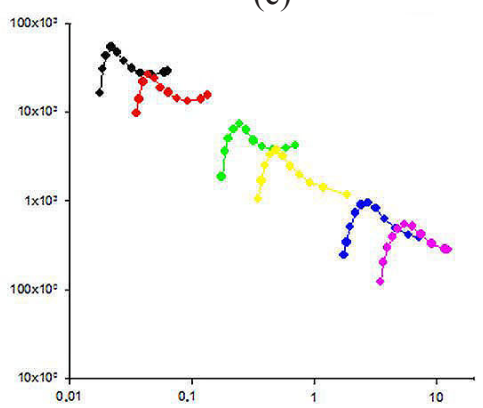

(f)

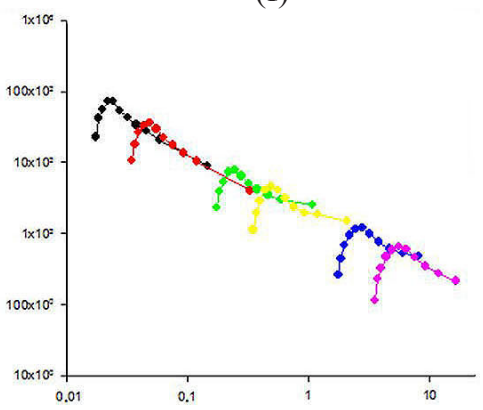

(i)

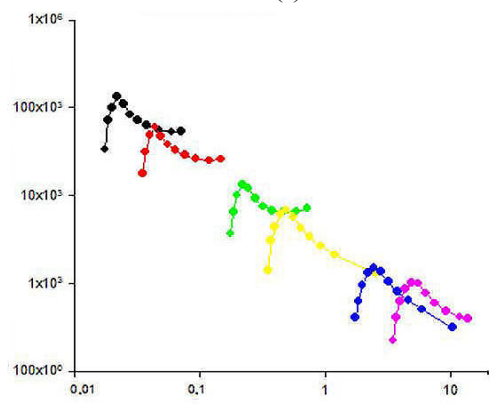

Biaxial extensional rate $\left(\mathrm{s}^{-1}\right)$

Figure 5: Apparent biaxial elongational viscosity versus biaxial extensional rate for mixed RS-WPI gels at (•) $0.05,(\bullet) 0.1,(\bullet) 0.5,(\bullet)$ 1, (•) 5 e (•) 10 mm/s in different concentrations: (a) 15-0, (b) 15-3, (c) 15-6, (d) 17.5-0, (e) 17.5-3, (f) 17.5-6, (g) 20-0, (h) 20-3 e (i) 20-6.

\section{CONCLUSIONS}

In the present study, three independent variables (RS concentration, WPI concentration, and test velocity) were studied. Box-Behnken experimental design was applied and proved to be effective in determining the dependent variables. The RS concentration and velocity had a more significant impact on the strength and stiffness of the gel. Mean while, the WPI concentration had little influence on the rigidity of the gel. Gel deformation was not dependent on any independent variables, showing that the gels had the same brittle behavior. The recoverable energy was highly dependent on the compression test velocity, i.e., the gels exhibited greater recovery when they were submitted to the maximum test velocity. This study shows the importance of knowing the characteristics of food product components when they are subjected to large deformations because they affect food product quality and customer acceptance in the market. 


\section{ACKNOWLEDGMENTS} support.

The authors thank FAPERJ and CNPq for financial

\section{REFERENCES}

BA-ABBAD, M. M. et al. Optimization of nickel oxide nanoparticles synthesis through the Sol Gel Method using Box-Behnken design. Materials \& Design, 86:948-956, 2015.

BAYRAKTAR, E. Response surface optimization of the separation of DL-tryptophan using an emulsion liquid membrane. Process Biochemistry, 37:169-175, 2001.

BOURNE, M. C. Food texture and viscosity: Concept and measurement. New York: Academic Press, 1982. 325p.

ÇAKIR, E. et al. The effect of microstructure on the sensory perception and textural characteristics of whey protein/kcarrageenan mixed gels. Food Hydrocolloids, 26:33-43, 2012.

CONSIDINE, T. et al. Rheological investigations of the interactions between starch and milk proteins in model dairy systems: A review. Food Hydrocolloids, 25(8):2008-2017, 2011.

DE JONG, S.; VAN DE VELDE, F. Charge density of polysaccharide controls microstructure and large deformation properties of mixed gels. Food Hydrocolloids, 21:1172-1187, 2007

DEJONG, S.; VANVLIET, T.; DEJONGH, H. H.J. The contribution of timedependent stress relaxation in protein gels to the recoverable energy that is used as a tool to describe food texture. Mechanics of Time-Dependent Materials, 19(4):505-518, 2015.

$\mathrm{ERSCH}, \mathrm{C}$. et al. Modulating fracture properties of mixed protein systems. Food Hydrocolloids, 44:59-65, 2015.

FRYDENBERG, R. P. et al. Protein denaturation of whey protein isolates (WPIs) induced by high intensity ultrasound during heat gelation. Food Chemistry, 192:415-423, 2016.

JHA, A. et al. Process optimization for manufacture of pearl millet-based dairy dessert by using response surface methodology (RSM). Journal of Food Science and Technology. 50(2):367-373, 2013.

KONG, X.; KASAPIS, S.; BAO, J. Viscoelastic properties of starches and flours from two novel rice mutants induced by gamma irradiation. LWT - Food Science and Technology, 60:578582, 2015.

MARFIL, P. H. M.; ANHÊ, A. C. B. N.; TELIS, V. R. N. Texture and microstructure of gelatin/corn starch-based gummy confections. Food Biophysics, 7:236-243, 2012.
MUNIALO, C. D.; VAN DER LINDEN, E.; DE JONGH, H. H. J. The ability to store energy in pea protein gels is set by network dimensions smaller than $50 \mathrm{~nm}$. Food Research International, 64:482-491, 2014.

MUNIALO, C. D. et al. Quantitative analysis of the network structure that underlines the transitioning in mechanical responses of pea protein gels. Food Hydrocolloids, 49:104$117,2015$.

MUNIALO, C. D. et al. The effect of polysaccharides on the ability of whey protein gels to either store or dissipate energy upon mechanical deformation. Food Hydrocolloids, 52:707-720, 2016.

RAMIRES-WONG, B. et al. Evaluation of the rheological properties of fresh corn masa using squeezing flow viscometry: Biaxial extentional viscosity. Journal of Texture Studies, 27:185-198, 1996.

ROSELL, C. M.; YOKOYAMA, W.; SHOEMAKER, C. Rheology of different hydrocolloids-rice starch blends. Effect of successive heating-cooling cycles. Carbohydrate Polymers, 84(1):373-382, 2011.

SADEGHI, M. et al. Acid-induced gelation behavior of casein/ whey protein solutions assessed by oscillatory rheology. Journal of Food Science and Technology, 51(9):21132119, 2014.

SAMUTSRI, W.; SUPHANTHARIKA, M. Effect of salts on pasting, thermal, and rheological properties of rice starch in the presence of non-ionic and ionic hydrocolloids. Carbohydrate Polymers, 87(2):1559-1568, 2012.

SHARMA, S.; BHATTACHARYA, S. Strain and strain rate dependence of gellan, agar and agar gellan gels as model systems. Journal of Food Engineering, 141:93-98, 2014.

SINGH, N. et al. Morphological, thermal and rheological properties of starches from different botanical sources. Food Chemistry, 81:219-231, 2003.

TAN, Y.; SUN, M.; CORKE, H. Physicochemical properties of an elite rice hybrid. Journal of the Science of Food and Agriculture, 82(14):1628-1636, 2002.

VITURAWONG, Y.; ACHAYUTHAKAN, P.; SUPHANTHARIKA, M. Gelatinization and rheological properties of rice starch/ xanthan mixtures: Effects of molecular weight of xanthan and different salts. Food Chemistry, 111(1):106-114, 2008.

WANG, Z. et al. The influence of agar gel texture on sucrose release. Food Hydrocolloids, 36:196-203, 2014. 